Nicholas, D. J. D. \& Mabey, G. L. (1960). J. gen. Microbiol. 22, 184-190

\title{
Some Properties of Glutamic Dehydrogenase from Neurospora crassa
}

\author{
By D. J. D. NICHOLAS AND G. L. MABEY \\ A.R.C. Unit of Plant Nutrition (Micronutrients), Long Ashton Research \\ Station, University of Bristol
}

SUMMARY: A glutamic dehydrogenase from Neurospora requiring either DPNH or TPNH for activity has a pH optimum of 8.6 and is inhibited by a number of chelating agents. The specific activity of the enzyme was high during early growth, but it fell sharply from the 2 nd to the 5th day after inoculation. A deficiency of $\mathrm{Zn}$ decreased enzyme activity and addition of the metal in vivo to $\mathrm{Zn}$-deficient mycelial felts restored the enzyme to normal values after a few days of incubation. The enzyme was unchanged when pyridoxine or riboflavin was limiting in the growth of mutants which require these vitamins. With a purified enzyme the $K_{m}$ values in mole/l. were as follows: $\alpha$-ketoglutarate $0.75 \times 10^{-2}$; TPNH, $2 \times 10^{-4}$; and DPNH, $2 \cdot 3 \times 10^{-4}$.

Several metal-dependent flavoproteins have been characterized in Neurospora which are concerned with the reduction of nitrate to ammonia (Nicholas \& Nason, 1954; Medina \& Nicholas, 1957). Glutamic dehydrogenase appears to be a key enzyme in Neurospora for the utilization of ammonia since, at the present time, there is no convincing evidence for an alternative assimilatory route involving organo-nitro compounds (Nicholas, 1957, 1959). Some properties of glutamic dehydrogenase of Neurospora are described in this paper.

\section{METHODS}

Organisms. Neurospora crassa macroconidial type 5297 a was kindly supplied by Dr W. D. McElroy, McCollum Pratt Institute, Johns Hopkins University Baltimore, U.S.A.

Culture medium. The fungus was grown in the following basal medium (g.): sucrose, 20; $\mathrm{NaNO}_{3}, 6.4 ; \mathrm{Na}$ tartrate, $1 ; \mathrm{KH}_{2} \mathrm{PO}_{4}, 3 ; \mathrm{MgSO}_{4} .7 \mathrm{H}_{2} \mathrm{O}, 0.5$; $\mathrm{NaCl}, 0.1 ; \mathrm{CaCl}_{2}, 0.1 ; \mathrm{FeCl}_{3} .6 \mathrm{H}_{2} \mathrm{O} 9.6 \times 10^{-4} ; \mathrm{ZnSO}_{4} .7 \mathrm{H}_{2} \mathrm{O}, 8.8 \times 10^{-3} ;$ $\mathrm{CuSO}_{4} .5 \mathrm{H}_{2} \mathrm{O}, 2.7 \times 10^{-4} ; \mathrm{MnCl}_{2} .4 \mathrm{H}_{2} \mathrm{O}, 7 \cdot 2 \times 10^{-5} ; \mathrm{Na}_{2} \mathrm{MoO}_{4} .2 \mathrm{H}_{2} \mathrm{O} 1.2 \times 10^{-5}$; biotin, 5 $\mu$ g.; deionized water (Permutit Deminrolit Mark IV plant) 11 . $\mathrm{NH}_{4} \mathrm{Cl}\left(3 \mathrm{~g}\right.$.) was substituted for $\mathrm{NaNO}_{3}$, in some cultures.

Removal of trace metals from culture medium. Methods reported elsewhere were used to remove trace metals from culture solutions (Nicholas, 1952). The mineral micronutrients, checked for purity with a spectrograph, were supplied by Johnson Matthey (Hatton Garden, London, E.C.1). The culture medium (200 ml.) was dispensed in 11 . Erlenmeyer flasks and after sterilizing at $10 \mathrm{lb}$./sq.in. for $15 \mathrm{~min}$. these were cooled and inoculated with a spore suspension of the fungus in sterile deionized water. The organism was grown at $30^{\circ}$ for 4 days unless otherwise stated. 
Preparation of acetone porwder of mycelium. The mycelial felts collected in a sintered funnel (no. 1 porosity) were well washed with cold deionized water and were suspended in water in a 5 l. beaker and aerated in the cold with air for $4 \mathrm{hr}$. to decrease the amount of endogenous substrates. After surplus water had been squeezed out of the felts they were transferred to a beaker containing acetone at $-15^{\circ}$ and put in a deep-freeze cabinet overnight. The felts were then well washed with cold acetone on a sintered funnel, squeezed between filter paper to remove excess acetone and dried quickly in a current of air. When dry the felts were crushed to a powder in a pestle and mortar and stored in a vacuum desiccator in the cold until required.

The glutamic dehydrogenase was extracted from the acetone powder in cold 0.1 M-phosphate buffer ( $\mathrm{pH} 8 \cdot 6$ ) by use of a Ten Broeck glass macerater. The homogenate was centrifuged at $4000 \mathrm{~g}$ and the supernatant solution used as a source of enzyme.

Assay of glutamic dehydrogenase. The enzyme was assayed by following the oxidation of DPNH at $340 \mathrm{~m} \mu$ in a $1 \mathrm{~cm}$. cell in a Unicam spectrophotometer. The cuvette contained, $2.5 \mathrm{ml}$. 0.1 M-phosphate buffer (pH 8.6); $0.1 \mathrm{ml}$. $0 \cdot 1 \mathrm{M}-\left(\mathrm{NH}_{4}\right)_{2} \mathrm{SO}_{4}, 0.1 \mathrm{ml} .10^{-3} \mathrm{M}-\mathrm{DPNH} ; 0.1 \mathrm{ml}$. enzyme extract. The endogenous rate was measured for $8 \mathrm{~min}$. and then $0.1 \mathrm{ml}$. 0.1 M-sodium $\alpha$-ketoglutarate added and the rate measured at $30 \mathrm{sec}$. intervals over a further $5 \mathrm{~min}$. period. Unit of enzyme activity was the change in $\log$. $I_{0} / I$ of $0.001 \mathrm{~min}$. calculated between 15 and 75 sec./mg. protein.

Protein determination. The Folin method of Lowry, Rosebrough, Farr \& Randall (1951) was used to determine the protein contents of the fractions.

Cofactors. DPN and TPN both $95 \%$ pure were obtained from Sigma Chemical Company, U.S.A. Reduced DPN was prepared enzymically by the alcohol dehydrogenase method of Pullman, Colowick \& Kaplan (1954) and reduced TPN by using the isocitric dehydrogenase enzyme from acetone powder of pig heart (Ochoa, 1955). Crystalline alcohol dehydrogenase was prepared by Racker's method (1956) from Acorn yeast, supplied by Distillers Company, Ltd., Bristol.

\section{RESULTS}

\section{Experiments with crude extracts containing glutamic dehydrogenase from Neurospora}

Time factor for assay. The relation between enzyme activity and incubation time is given in Fig. 1. The rate was linear over the first 5 min. and then it decreased because DPHN was limiting. When further amounts of DPNH were added a linear rate was maintained.

Amounts of enzyme. Increasing amounts of crude extract (0.01-0.2 ml.) resulted in a linear response in enzyme activity as shown in Fig. 2.

$p H$ optimum. The effect of $\mathrm{pH}$ on enzyme activity is illustrated in Fig. 3; maximum rate was obtained at $\mathrm{pH} 8 \cdot 6$.

Enzyme production in felts. Enzyme activity/mg. protein was high during early growth (Fig. 4), but it decreased rapidly during the log. phase of growth. 
After 5 days, when growth had reached its maximum, the enzyme activity was not further decreased.

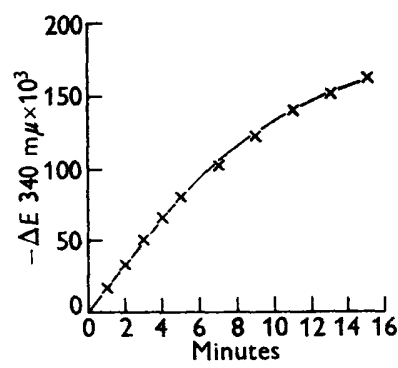

Fig. 1

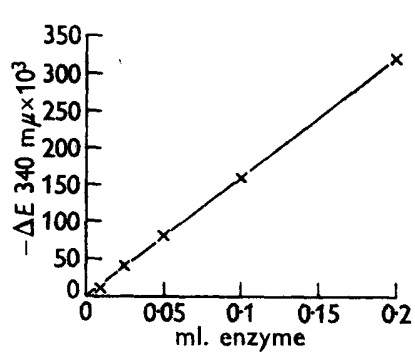

Fig. 2

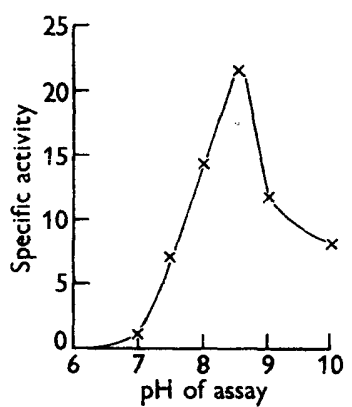

Fig. 3

Fig. 1. Relation between Neurospora-glutamic dehydrogenase activity and incubation time. Curvette contained: $2.5 \mathrm{ml}$. 0.1 M-phosphate buffer (pH 8.6); 0.1 ml. 0.2 M-ammonium sulphate; 0.1 ml. 10-8 M-DPNH; 0.1 ml. enzyme. Endogenous rate measured at $340 \mathrm{~m} \mu$; then $0.1 \mathrm{ml} .0 \cdot 1 \mathrm{M}$-sodium $\alpha$-ketoglutarate added. Unit of activity was the change in $I_{0} / I$ of $0.001 / \mathrm{min}$. calculated between 15 and 75 sec. $/ \mathrm{mg}$. protein.

Fig. 2. Relation between the volume of crude extract of Neurospora added and glutamic dehydrogenase activity. Assay as in Fig. 1 (enzyme as indicated).

Fig. 3. Effect of $\mathrm{pH}$ on activity of glutamic dehydrogenase from Neurospora. Assay as for Fig. 1. The buffers used to extract the enzyme from acetone powder of mycelium were: pH range $6 \cdot 0-8.5=0.1 \mathrm{M}$-phosphate suitably adjusted; pH range $8 \cdot 5-10 \cdot 0=0.1 \mathrm{M}$ glycine suitably adjusted.

Effect of inhibitors. A number of metal-binding inhibitors decreased enzyme activity, but 8-hydroxyquinoline at a relatively high concentration was without effect and $o$-phenanthroline was relatively ineffective (Table 1).

Table 1. Effect of inhibitors on glutamic dehydrogenase of Neurospora

The enzyme preparation was incubated with inhibitor for $10 \mathrm{~min}$. at $37^{\circ}$ before assay.

\begin{tabular}{lcc}
\multicolumn{1}{c}{ Inhibitor } & $\begin{array}{c}\text { Final concentration } \\
(\mathbf{M})\end{array}$ & $\begin{array}{c}\text { Inhibition } \\
(\%)\end{array}$ \\
o-Phenanthroline & $\mathbf{3 \times 1 0 ^ { - 2 }}$ & $\mathbf{2 0}$ \\
Na ethylenediamine tetra-acetate & $1 \times 10^{-2}$ & 65 \\
8-Hydroxyquinoline & $\mathbf{3} \times 10^{-4}$ & 0 \\
Na-diethyldithiocarbamate & $5 \times 10^{-2}$ & 45 \\
Sodium azide & $1 \times 10^{-1}$ & 65 \\
Sodium sulphide & $3 \times 10^{-2}$ & 45 \\
Thiourea & $2 \times 10^{-2}$ & 85
\end{tabular}

Metal and vitamin deficiencies. A deficiency of $\mathrm{Zn}$ in the medium during growth decreased the specific activity of the enzyme in the mycelium (Table 2). This occurred whether nitrate- $N$ or ammonium- $N$ was the sole source of nitrogen. Other metal deficiencies had relatively little effect on the enzyme.

The $30 \%$ decrease in enzyme activity when Mo was deficient might have resulted from a smaller nitrate-reductase activity, thus limiting the amount of ammonia formed from the nitrate which was the sole source of nitrogen. When ammonia-N was substituted for nitrate-N, however, Mo deficiency had no effect on the dehydrogenase. The dehydrogenase was unchanged in 


\section{Glutamic dehydrogenase from Neurospora}

riboflavin- and pyridoxine-requiring mutants of Neurospora harvested from media deficient in these vitamins.

Table 2. Effects of trace-metal deficiencies on glutamic dehydrogenase activity in Neurospora crassa

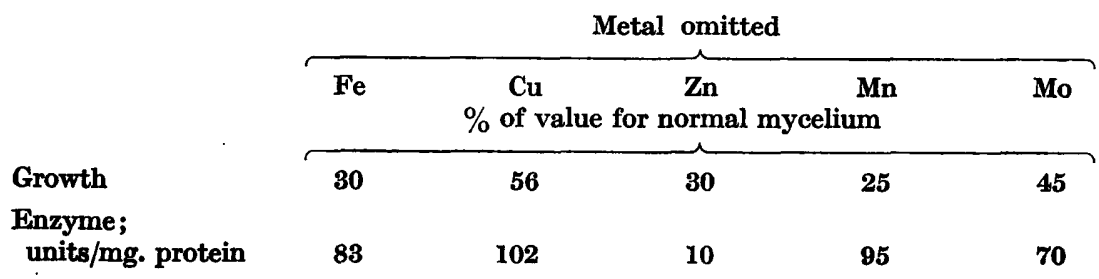

Graded amounts of $\mathrm{Zn}$ in the culture media increased enzyme activity in the mycelium (Fig. 5). The enzyme was reconstituted when $\mathrm{Zn}$ was added after growth for 2 days to $\mathrm{Zn}$-deficient mycelial felts (Fig. 6). No other metal had this effect.

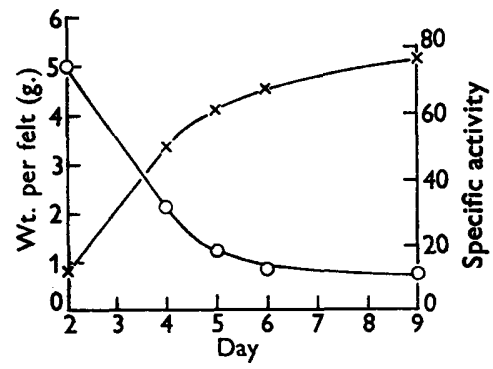

Fig. 4

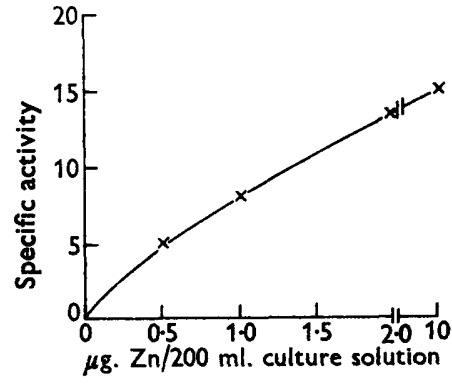

Fig. 5

Fig. 4. Glutamic dehydrogenase activity of Neurospora mycelial felts grown for different lengths of time. Assay as for Fig. 1. $x-x=$ weight/felt (g.); $\mathrm{O}-\mathrm{O}=$ specific enzyme activity.

Fig. 5. Effect of zinc content of medium on the glutamic dehydrogenase activity of crude extracts of acetone powder of Neurospora mycelium. Assay as for Fig. 1.

\section{Experiments with purified Neurospora glutamic dehydrogenase}

Fractionation of the enzyme. A tenfold purification of the enzyme was achieved as indicated in Table 8. The crude extract in $0.01 \mathrm{~m}$-phosphate buffer (pH 8.6) was prepared from $5 \mathrm{~g}$. acetone powder. The homogenate was centrifuged at $4000 \mathrm{~g}$. The precipitate collected at $30-60 \%$ saturation with ammonium sulphate contained all the enzyme present in the crude extract. The first calcium phosphate gel treatment removed about half of the protein while retaining in the supernatant solution more than two-thirds of the enzyme (fraction 111). Fraction 5 was used for subsequent experiments.

Substrate saturation. The substrate saturation for sodium $\alpha$-ketoglutarate is illustrated in Fig. 7 , the $K_{m}$ value was $0.75 \times 10^{-2}$ mole/l. for the purified enzyme. The following keto acids could not replace $\alpha$-ketoglutarate in this reaction, namely: pyruvic, oxalacetate and oxalosuccinate. 
Coenzyme saturation. The data presented in Fig. 8 show that the purified enzyme had greater affinity for TPNH than for DPNH. The $K_{m}$ values (mole/l.) were: $2.0 \times 10^{-4}$ for TPNH, and $2.3 \times 10^{-4}$ for DPNH.
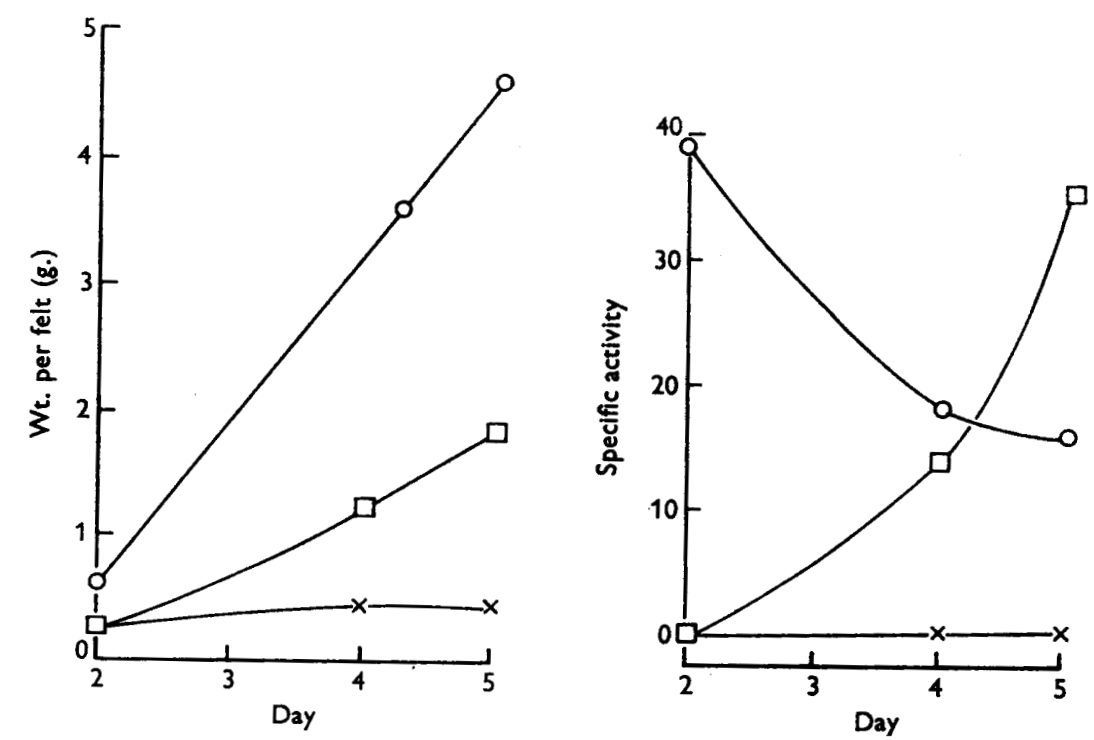

Fig. 6. Restoration of the growth and glutamic dehydrogenase activity in zinc-deficient Neurospora mycelium. $O-O=$ mycelium grown on complete medium; $x-x=$ mycelium grown without zinc; $\square-\square=2 \mathrm{mg}$. $\mathrm{Zn} / \mathrm{l}$. added aseptically to zinc-deficient cultures after two days of growth. Weight and enzyme activity measured at the fourth and fifth days.

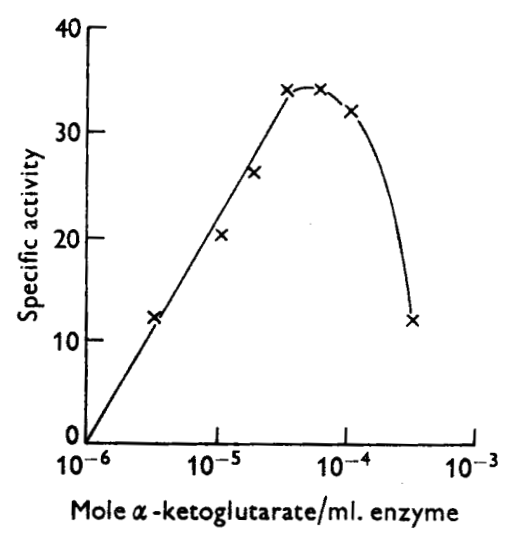

Fig. 7

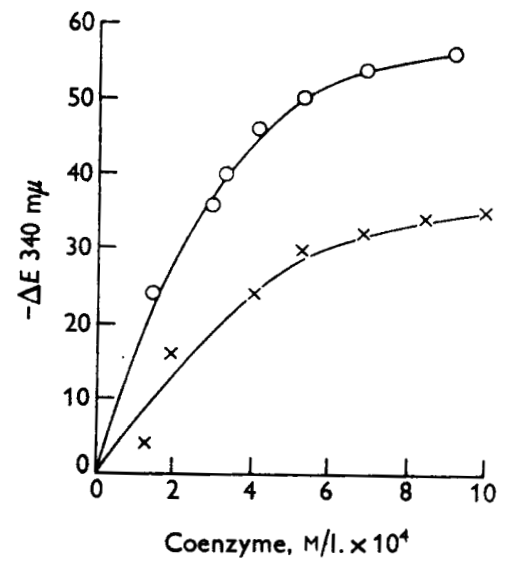

Fig. 8

Fig. 7. Substrate saturation $\left(K_{m}\right)$ for glutamic dehydrogenase of Neurospora. Enzyme from fraction (5) in Table 8. Assay as for Fig. 1.

Fig. 8. Coenzyme saturation $\left(K_{m}\right)$ for glutamic dehydrogenase of Neurospora. Enzyme from fraction (5) in Table 3. Assay as for Fig. 1. $0-0=$ with TPNH; $x-x=$ with DPNH. 
Table 3. Fractionation of glutamic dehydrogenase from Neurospora crassa wild-type 5297 a

I. Crude extract in $0.01 \mathrm{M}$-phosphate Fraction (pH 8.6)

II. Ppt. from 30-60\% saturation with ammonium sulphate of fraction $I$, dissolved in 0.01 x-phosphate (pH 8*6)

III. Calcium phosphate gel added to fraction II, $5 \mathrm{mg} . / 100 \mathrm{mg}$. protein, stirred and centrifuged immediately. Supernatant solution assayed

IV. Further amounts of calcium phosphate gel added to fraction III, $40 \mathrm{mg} . / 100 \mathrm{mg}$. protein. Stand 15 min., centrifuge. Gel washed twice with 0.01M-phosphate buffer (pH 8.6) and then enzyme eluted from it with $0 \cdot 1$ x-pyrophosphate buffer (pH 8.6). Activity of eluate

v. Carbont added and stirred into fraction IV, $25 \mathrm{mg} . / \mathrm{mg}$. protein. Activity of supernatant solution after centrifuging

\begin{tabular}{|c|c|c|c|}
\hline $\begin{array}{l}\text { Total } \\
\text { protein } \\
\text { (mg.) }\end{array}$ & $\begin{array}{c}\text { Total } \\
\text { enzyme } \\
\text { (units) }\end{array}$ & $\begin{array}{c}\text { Enzyme } \\
\text { specific } \\
\text { activity* } \\
\text { (units/mg. } \\
\text { protein) }\end{array}$ & $\begin{array}{c}\text { Recovery } \\
\text { of } \\
\text { enzyme } \\
(\%)\end{array}$ \\
\hline 424 & 8800 & 21 & 100 \\
\hline 238 & 9000 & 38 & 102 \\
\hline 133 & 6500 & 49 & 74 \\
\hline 35 & 3000 & 86 & 34 \\
\hline 10 & 2250 & 225 & 25 \\
\hline
\end{tabular}

\section{DISCUSSION}

Several metal-binding compounds decreased the activity of glutamic dehydrogenase from Neurospora but, unlike the crystalline enzyme from beef liver (Adelstein \& Vallee, 1959), it was not inhibited by o-phenanthroline or by 8-hydroxyquinoline. It is of interest that the glutamic dehydrogenase in Neurospora is dependent on $\mathrm{Zn}$ for its formation, since it has been shown that the dehydrogenases prepared from liver contains 2-4 g. atom zinc/mole protein (Adelstein \& Vallee, 1958). Further purification of the Neurospora enzyme will be necessary to determine whether or not $\mathrm{Zn}$ is a constituent of it. In the reduction of nitrate to ammonia in micro-organisms it has already been shown that trace metals play an important part in the formation and functioning of these enzymes. It now seems clear that the enzyme which controls the entry of the key intermediate ammonia into an organic molecule in Neurospora is dependent on zinc for its formation. 


\section{REFERENCES}

Adelstern, S. J. \& Valleee, B. L. (1958). Zinc in beef liver glutamic dehydrogenase. J. biol. Chem. 233, 589.

Adelstern, S. J. \& Vaunee, B. L. (1959). The inhibition of beef liver glutamic hydrogenase by metal-binding agents. J. biol. Chem. 234, 824.

Lowry, O. H., Rosebrough, N. J., Farr, A. L. \& Randall, R. J. (1951). Protein measurement with the Folin phenol reagent. J. biol. Chem. 193, 265.

Medina, A. \& Nicholas, D. J. D. (1957). Metalloenzymes in the reduction of nitrite to ammonia in Neurospora. Biochim. biophys. Acta, 25, 138.

NicholAs, D. J. D. (1952). The use of fungi for determining trace metals in biological materials. Analyst, 77, 629.

Nicholas, D. J. D. \& Nason, A. (1954). The mechanism of action of nitrate reductase from Neurospora. J. biol. Chem. 211, 183.

NrCholas, D. J. D. (1957). Role of trace metals in the nitrogen metabolism of plants with special reference to micro-organisms. J. Sci. Food Agric. 8, Suppl. issue S. 15.

NIChоцAs, D. J. D. (1959). Metallo-enzymes in nitrate assimilation of plants with special reference to micro-organisms. Utilization of Nitrogen and its Compounds by Plants. Symp. Soc. exp. Biol. 13, 1.

OchоA, S. (1955). Isocitric dehydrogenase system (TPN) from pig heart. In Methods in Enzymology, ed. S. P. Colowick \& N. O. Kaplan, vol. 2, p. 655. New York: Academic Press Inc.

Pullman, M., Colowick, S. P. \& Kaplan, N. O. (1954). Comparison of diphosphopyridine nucleotide with its deaminated derivative in various enzyme systems. J. biol. Chem. 194, 593.

RACKER, E. (1955). Alcohol dehydrogenase from Baker's yeast. Methods in Enzymology, ed. S. P. Colowick \& N. O. Kaplan, vol. 1, p. 500. New York: Academic Press Inc.

(Received 14 July 1959) 